\title{
Tinjauan Fiqh Muamalah tentang Upah Pemeliharaan Hewan Ternak pada Akad Ijarah (Praktik Gaduh Sapi)
}

\author{
Ai Siti, Ifa Hanifia Senjiati, Amrullah Hayatudin \\ Prodi Hukum Ekonomi Syariah, Fakultas Syariah, Universitas Islam Bandung \\ Jl. Tamansari No. 1 Bandung 40116 \\ Aisiti272@gmail.com, Ifa.wahyudin@gmail.com, Amrullah Hayatudin@gmail.com
}

\begin{abstract}
The Ijarah contract is a contract whose object is the exchange of benefits for a certain period, that is the ownership of benefits in return, is the same as selling benefits. Ijarah is divided into two types namely, Ijarah which leads to wage wage ('ala al-asykhash), which is of service nature as is the case with livestock raising in Kampung Cipondok, District of Cigedug, Garut Regency. The formulation of the problem is: How is the Wage Theory of Livestock in Muamalah Jurisprudence? What is the Practice of Giving Wages to Cattle Keepers with the Ijarah Agreement in Cipondok Village, Cigedug District, Garut Regency? How is the Muamalah Fiqh Analysis on the Wage Practice of Cattle Livestock Maintenance in Cipondok Village, Cigedug District, Garut Regency?
\end{abstract}

This study aims to determine the theory of livestock maintenance wages in Muamlah Jurisprudence, knowing the practice of giving wages to livestock raising, knowing the analysis of Muamalah Jurisprudence on the practice of livestock raising wages in Cipondok Village, Cigedug Subdistrict, Garut Regency, is it in accordance with Islamic Sharia. The research method used was qualitative, interview, literature study, documentation.

Based on Muqalah Fiqh analysis in terms of the Ijarah contract, the service of raising cattle in Cipondok Village is said to be illegal if it is associated with Ibn Majah's Hadith because the maintenance of cattle is entitled to wages, because the cattle keeper has fulfilled his obligations as a livestock keeper service

Keywords-Fiqh Muamalah, Ijarah Covenant, Rearing Livestock

Abstrak -Akad Ijarah adalah akad yang objeknya ialah penukaran manfaat untuk masa tertentu, yaitu pemilikan manfaat dengan imbalan, sama dengan menjual manfaat. Ijarah dibagi menjadi dua macam yaitu, Ijarah yang mengarah kepada upah mengupah ('ala al-asykhash) yaitu bersifat jasa seperti halnya dengan pemeliharaan hewan ternak di Kampung Cipondok Kecamatan Cigedug Kabupaten Garut. Rumusan masalah yaitu: Bagaimana Teori Upah Pemeliharaan Hewan Ternak dalam Fikih Muamalah ? Bagaimana Praktik Pemberian Upah pada Pemelihara Sapi dengan Akad Ijarah di Kampung Cipondok Kecamatan Cigedug Kabupaten Garut ? Bagaimana Analisis Fiqh Muamalah Terhadap Praktik Upah Pemaliharaan Hewan Ternak sapi di Kampung Cipondok Kecamatan Cigedug Kabupaten Garut?

Penelitian ini bertujuan untuk mengetahui teori upah pemeliharaan hewan ternak dalam Fikih Muamlah, mengetahui praktik pemberian upah pada pemeliharaan hewan ternak, mengetahui analisis Fikih Muamalah terhadap praktik upah pemeliharaan hewan ternak di Kampung Cipondok Kecamatan Cigedug Kabupaten Garut, apakah sudah sesuai dengan Syari'at Islam. Metode Penelitian yang digunakan adalah menggunakan Kualitatif, Wawancara, Studi Kepustakaan, Dokumentasi.

Berdasakan analisis Fiqh Muamalah ditinjau dari akad Ijarah, jasa pemelihara hewan ternak sapi di Kampung Cipondok dikatakan tidak sah jika dikaitkan dengan Hadits Ibnu Majah karena pemeliharaan hewan ternak sapi berhak mendapatkan upah, karena si pemelihara hewan ternak sapi sudah memenuhi kewajibanya sebagai jasa pemelihara hewan ternak sapi.

Kata kunci -Fikih Muamalah, Akad Ijarah, Pemeliharaan Hewan Ternak

\section{PENDAHULUAN}

Sebagai makhluk sosial manusia tidak dapat hidup sendiri, artinya bahwa manusia selalu berhubungan dan membutuhkan orang lain. Salah satunya yaitu dalam bidang muamalah. Muamalah adalah tukar menukar barang atau sesuatu yang bermanfaat dengan cara yang telah ditentukan.1 Dalam hal muamalah, Islam telah memberikan ketentuan-ketentuan atau kaidah-kaidah yang harus ditaati dan dilaksanakan. Jadi pelaksanaan muamalah harus sesuai dengan ketentuan yang sudah ditetapkan oleh syari'at Islam.

Allah telah menjadikan manusia masing-masing berhajat kepada yang lain, supaya mereka tolongmenolong, tukar-menukar keperluan dalam segala urusan kepentingan hidup masing-masing, baik dengan cara jual beli, sewa menyewa, bercocok tanam atau yang lain, baik dalam urusan diri sendiri maupun untuk kemaslahatan umum. 2

Berdasarkan hasil survey awal, penulis melihat pelaksanaan dalam upah mengupahnya tidak jelas karena pemelihara sapi tersebut diberi upah dengan seekor anak sapi, jika sapi tersebut melahirkan hanya satu ekor maka pemelihara sapi tersebut tidak mendapatkan upah, dan anak sapi tersebut diberikan hanya untuk pemilik sapi, jika sapi melahirkan lebih dari satu ekor maka akan dibagi dua 
untuk pemilik dan pemelihara sapi. Kasus di atas sangatlah perlu dikaji lebih lanjut dengan lebih memperdalam masalah apa yang mendasari terjadinya hal-hal tersebut terutama jika dikaitkan dalam fikih muamalah tentang akad ijarah. Maka dari itu permasalahan di atas bertentangan dengan prinsip hukum muamalah sehingga terjadinya tanggung jawab yang bertujuan tidak ada pihak yang dirugikan.

Berdasarkan dari latar belakang di atas, penulis tertarik melakukan penelitian dalam bentuk skripsi dengan judul "Tinjauan Fiqh Muamalah Tentang Upah Pemeliharaan Hewan Ternak pada Akad Ijarah (Praktik Gaduh Sapi) di Kampung Cipondok Kecamatan Cigedug Kabupaten Garut”. 